\title{
Investigation of Factors Affecting the Stone-Free Rate in Elderly Patients with Urinary Stones After Shock Wave Lithotripsy
}

\author{
İdrar Taşı Olan Yaşıı Hastalarda Şok Dalgası Litotripsi Sonrası Taşsızlık Oranını Etkileyen \\ Faktörlerin Araştırılması
}

\author{
Alpaslan YÜKSEL \\ (D) 0000-0003-0076-4812 \\ Dursun BABA \\ (D) 0000-0002-4779-6777 \\ Yusuf ŞENOĞLU \\ (D) 0000-0002-3072-9252 \\ Arda Taşkın TAŞKIRAN \\ (D) 0000-0003-4556-3475
}

Department of Urology, Düzce University Faculty of Medicine, Düzce, Turkey

\section{Corresponding Author Sorumlu Yazar \\ Alpaslan YÜKSEL \\ dralpyuksel@gmail.com}

Received / Geliş Tarihi : 06.10.2021 Accepted / Kabul Tarihi : 01.12.2021 Available Online /

Çevrimiçi Yayın Tarihi : 10.12.2021

\begin{abstract}
Aim: Urinary stone disease is an important disease seen in all age groups, including elderly patients. It can cause kidney failure and urinary infection problems. Shock wave therapy, which is the minimal invasive among the different treatment alternatives, is preferred for kidney and proximal ureteral stones smaller than $2 \mathrm{~cm}$. Studies on the efficacy and safety of this treatment in elderly patients are limited. This study aimed to investigate the factors affecting the stone-free rate (SFR) in elderly patients with urinary stones after shock wave lithotripsy.

Material and Methods: The data of 120 patients in the Urology department of Duzce University Faculty of Medicine between 2010 and 2018 over 65 years old who underwent extracorporeal shock wave lithotripsy (ESWL) for urinary system stone disease were evaluated retrospectively. The data obtained from these patients included sex, age, location of the stone (upper, middle, or lower calyx, renal pelvis, ureter), number of shock waves, stone size, and the need for the auxiliary procedure were analyzed.

Results: Of the 120 patients, $82(68.3 \%)$ were male and 38 (31.7\%) were female. Comorbidity was present in 49 patients. An overall SFR of $65.8 \%(n=79)$ was found. The highest SFR was found in middle calyx stones with $79.3 \%$ (23 of the 29 patients). Post-ESWL auxiliary procedures were needed in $36(30 \%)$ patients. Two patients developed subcapsular renal hematoma and pyelonephritis.

Conclusion: ESWL is an appropriate even the first option for elder male with favorable stone size. Furthermore, ESWL caused acceptable morbidity in older patients.

Keywords: comorbidities; elderly; extracorporeal shock wave lithotripsy; urolithiasis.
\end{abstract}

ÖZ

Amaç: Üriner taş hastalığı, yaşlı hastalar da dahil olmak üzere tüm yaş gruplarında görülen önemli bir hastalıktır. Böbrek yetmezliği ve idrar yolu enfeksiyonu sorunlarına neden olabilir. Farklı tedavi alternatifleri arasında minimal invaziv olan şok dalga tedavisi böbrek ve proksimal üreter taşlarında $2 \mathrm{~cm}$ 'den küçük olanlarda tercih edilmektedir. Yaşlı hastalarda bu tedavinin etkinliği ve güvenliği ile ilgili çalışmalar sınırlıdır. Bu çalışmada, üriner taşları olan yaşlı hastalarda şok dalga litotripsi sonrası taşsızlık oranını (stone-free rate, SFR) etkileyen faktörlerin araştırılması amaçlanmıştır.

Gereç ve Yöntemler: 2010 ve 2018 yılları arasında Düzce Üniversitesi Tıp Fakültesi Üroloji Anabilim Dalı'nda üriner sistem taş hastalığı nedeniyle ekstrakorporeal şok dalga litotripsi (extracorporeal shock wave lithotripsy, ESWL) uygulanan 65 yaş üstü 120 hastanın verileri retrospektif olarak değerlendirildi. Bu hastalardan elde edilen cinsiyet, yaş, taşın bulunduğu yer (üst, orta veya alt kaliks, renal pelvis, üreter), şok dalgalarının sayısı, taş boyutu ve yardımcı prosedüre duyulan ihtiyacı içeren veriler analiz edildi.

Bulgular: 120 hastanın 82'si $(\% 68,3)$ erkek, 38'i (\%31,7) kadındı. 49 hastada komorbidite mevcuttu. Toplam SFR \%65,8 (n=79) olarak bulundu. En yüksek SFR \%79,3 (29 hastanın 23 'ü) ile orta kaliks taşlarında bulundu. 36 (\%30) hastada ESWL sonrası yardımcı prosedürlere ihtiyaç duyuldu. İki hastada subkapsüler renal hematom ve piyelonefrit gelişti.

Sonuç: ESWL, uygun taş boyutuna sahip yaşlı erkekler için bile ilk seçenektir. Ayrıca, ESWL yaşlı hastalarda kabul edilebilir morbiditeye neden olmuştur.

Anahtar kelimeler: komorbidite; yaşlı; ekstrakorporal şok dalga tedavisi; urolitiyazis. 


\section{INTRODUCTION}

Urinary system stone disease is an important disease whose incidence has increased significantly in recent years and is thought to affect approximately $11 \%$ of the world population (1). Urinary system stone disease can be seen in different age groups, including the elderly patients (2). It is predicted that the number of individuals over the age of 65 will double in 2050. The ratio of urinary stone disease in elderly patients will increase in proportion to this number (3). The handicap of elderly individuals is that they are more fragile due to comorbidity and are prone to physical and psychological weakness (4). Although urinary system stone disease mainly affects adults aged 20-60 years old, elderly patients over the age of $>65$ constitute $10 \%$ to $20 \%$ of all stone patients (5-7). Elderly patients have an increased risk of kidney stone formation due to slowing metabolism, taking drugs and vitamin supplements that change their metabolic profiles, and decreasing water consumption (8).

Medical expulsive therapy (MET) is recommended for patients presenting with stones smaller than $5 \mathrm{~mm}$ in size with oral fluid intake and non-steroidal anti-inflammatory drugs (NSAIDs). Calcium channel blockers or $\alpha$-adrenergic antagonists that provide ureteral smooth muscle relaxation are added to the treatment. However, compared with younger patients, elderly patients with stones are more likely to fail MET therapy and require surgical intervention (9).

There are different alternatives in the treatment of urinary system stone disease, and the scale of the treatment ranges from minimally invasive methods to invasive methods. Percutaneous nephrolithotomy is the standard treatment for patients with kidney stones $>2 \mathrm{~cm}$, while ureteroscopy or extracorporeal shock wave lithotripsy (ESWL) is recommended for smaller stones (10). Each treatment alternative has its advantages and disadvantages, especially in the elderly population. ESWL is the preferred method, especially in renal and ureteral stones smaller than $2 \mathrm{~cm}$ (11). While the current stone treatment guidelines guide in managing adult patients, they are not very clear in elderly patients (12). Data on the efficacy of ESWL treatment in elderly patients with stones are limited in the literature. We aimed to research the factors related to the stone-free rate (SFR) in elderly patients with urinary stones after shock wave lithotripsy.

\section{MATERIAL AND METHODS}

In this study, the records of 120 patients over 65 years old who received ESWL treatment in the Urology department of Duzce University Faculty of Medicine between 2010 and 2018 were retrospectively reviewed. During this period, 1706 patients underwent ESWL and 7\% were over 65 years old. Medical history, physical examination, urinalysis, urine culture and creatinine values of the patients were recorded. The data obtained from these patients included sex, age, location of the stone (ureter, lower calyx, middle calyx, upper calyx or renal pelvis), number of shock waves, size of the stone, and the need for the auxiliary procedure were analyzed.

The stones of the patients were evaluated with intravenous pyelography (IVP) or computed tomography (CT) of the abdomen. All patients were required to have stones of less than 20 millimeters in the kidney or proximal ureter, radiopaque on X-ray imaging, and no contraindications for ESWL. Patients with suspected ureteral stenosis, coagulopathies and dysfunctional kidneys were excluded from the study.

Comorbidities of the patients were recorded. Anticoagulant drugs of the patients were discontinued seven days before and $60 \mathrm{mg}$ of enoxaparin sodium was started. The same protocol was applied to all patients with anticoagulant medication. Half an hour before the procedure, i.m. $75 \mathrm{mg}$ of diclofenac sodium was administered to all patients for analgesia. PCK Stonelith-V3 brand ESWL device was applied to all patients in each session. The average number of shocks applied per stone in one session was $2800 \pm 500$; the average voltage was $18.4 \pm 1.2 \mathrm{kV}$. One week after each ESWL session, the form of the stone was evaluated by direct X-ray or ultrasound. The absence of any stones or presence of $\leq 4 \mathrm{~mm}$ fragments was considered stone-free, which means ESWL success and the presence of $>4 \mathrm{~mm}$ fragments of stone were considered ESWL failure. Re-treatment was performed if $>4 \mathrm{~mm}$ fragments of stone were observed. If there was no response after repetitive sessions, the case was considered as ESWL failure. Follow-up was done by kidney, ureter, and bladder X-ray and renal ultrasound every week until ESWL success. All data were collected and analyzed after the 2-month.

The study protocol was approved by the institutional ethics committee, Non-interventional Clinical Research Ethics Committee of Duzce University $(06.10 .2015,51)$.

\section{Statistical Analysis}

Normality assumption was examined with the Kolmogorov-Smirnov test. Comparisons of continuous variables between groups were done with the Independent samples t-test or Mann-Whitney U test, according to the normality assumption. Categorical data were analyzed with Pearson chi-square or Fisher's exact test, as appropriate. Descriptive statistics were given as mean \pm standard deviation or median, interquartile range, and minimum-maximum values for numerical variables, while categorical variables were presented as number and percentage. IBM SPSS v.22 statistical package was used for statistical analyses and a p-value of 0.05 was considered as statistical significance level.

\section{RESULTS}

A total of 120 patients over 65 years of age were included in this study. The mean age of the patients was $66.77 \pm 2.04$ years, with a maximum of 79 years. Of the 120 patients, $82(68.3 \%)$ were male and $38(31.7 \%)$ were female. All patients had only one stone. A total of $46(38.3 \%)$ patients had past histories of urolithiasis. Total of 56 comorbidities following were present in 49 patients; arterial hypertension (HT) in 32 (26.7\%), diabetes mellitus (DM) in $15(12.5 \%)$, coronary artery disease (CAD) in $5(4.2 \%)$, and the other comorbidities in $4(3.3 \%)$ were recorded. The details of the patients are summarized in Table 1.

The mean length of the stone sizes was $10.17 \pm 3.38 \mathrm{~mm}$, and the longest stone size was $21 \mathrm{~mm}$. A SFR of $65.8 \%(\mathrm{n}=79)$ was found. The highest SFR with a rate of $79.3 \%$ ( 23 of the 29 patients) was found in middle calyx stones (Table 2). 
A comparison of demographic and clinical characteristics of the patients with and without successful treatment was given in Table 3. There was no statistically significant difference in SFR of the patients, in terms of gender $(\mathrm{p}=0.684)$, comorbidity $(\mathrm{p}=0.495)$, smoking $(\mathrm{p}=0.659)$, stone history $(p=0.911)$, family history $(p=0.763)$, creatinine level of $\geq 1.2(p=0.683)$, stone side $(p=0.760)$ and stone location $(\mathrm{p}=0.228)$.

While there was no statistically significant difference was found between the patients with successful and unsuccessful treatment in terms of age $(p=0.284)$ and creatinine level $(\mathrm{p}=0.874)$, stone size $(\mathrm{p}=0.022)$ and the number of ESWL sequences $(p=0.008)$ were higher in patients with unsuccessful treatment (Table 4).

Auxiliary procedures were needed in $36(30 \%)$ of the patients in this study. Ureterorenoscopy was performed in $23(63.9 \%)$ patients, percutaneous nephrolithotomy was performed in $9(25 \%)$ and double $\mathrm{J}$ stent was placed in $4(11.1 \%)$ patients. Despite successful ESWL treatment, a double $\mathbf{J}$ stent was placed in 2 patients and

Table1. Characteristics of the patients and the stone $(n=120)$

\begin{tabular}{lc}
\hline Age (years), mean $\pm \mathrm{SD}($ min-max) & $66.77 \pm 2.04(65-79)$ \\
Gender, n (\%) & \\
Male & $82(68.3)$ \\
Female & $38(31.7)$ \\
Comorbidities, n (\%) & \\
HT & $32(26.7)$ \\
DM & $15(12.5)$ \\
CAD & $5(4.2)$ \\
Other & $4(3.3)$ \\
Smoking, n (\%) & $35(29.2)$ \\
Stone history, n (\%) & $46(38.3)$ \\
Family history, n (\%) & $16(13.3)$ \\
Creatinine $\geq 1.2, n(\%)$ & $29(24.2)$ \\
Side, n (\%) & \\
Left & $65(54.2)$ \\
Right & $55(45.8)$ \\
Location, n $(\%)$ & \\
Upper & $6(5.0)$ \\
Middle & $29(24.2)$ \\
Lower & $20(16.7)$ \\
Pelvis & $17(14.2)$ \\
Proximal & $48(40.0)$ \\
Sto
\end{tabular}

Stone size (mm), mean \pm SD (min-max) $\quad 10.17 \pm 3.38$ (4-21)

HT: hypertension, DM: diabetes mellitus, CAD: coroner artery disease, SD: standard deviation

Table 2. The relationship between stone location and stone-free rate, $\mathrm{n}(\%)$

\begin{tabular}{lcc}
\hline Stone location & Total & Stone-free rate \\
\hline Upper calyx & $6(5.0 \%)$ & $3(50.0 \%)$ \\
Middle calyx & $29(24.2 \%)$ & $23(79.3 \%)$ \\
Lower calyx & $20(16.7 \%)$ & $15(75.0 \%)$ \\
Kidney pelvis & $17(\% 14.2)$ & $9(\% 52.9)$ \\
Proximal ureter & $48(\% 40.0)$ & $29(\% 60.4)$ \\
\hline Total & $120(\% 100)$ & $79(\% 65.8)$ \\
\hline
\end{tabular}

ureterorenoscopy was performed in 2 patients due to ureteral obstruction.

Subcapsular renal hematoma and pyelonephritis developed in 2 patients in terms of major complications. The patients were hospitalized and no surgical intervention was needed in follow-up.

Table 3. Comparison of stone free rates according to the demographic and clinical characteristics of the patients

\begin{tabular}{|c|c|c|c|}
\hline Characteristics & $\mathbf{n}$ & SFR & $\mathbf{p}$ \\
\hline \multicolumn{4}{|l|}{ Gender, n (\%) } \\
\hline Male & 82 & $53(64.6)$ & \multirow{2}{*}{0.684} \\
\hline Female & 38 & $26(68.4)$ & \\
\hline \multicolumn{4}{|c|}{ Comorbidity, n (\%) } \\
\hline No & 71 & $45(63.4)$ & \multirow{2}{*}{0.495} \\
\hline Yes & 49 & $34(69.4)$ & \\
\hline \multicolumn{4}{|l|}{ DM, n (\%) } \\
\hline No & 105 & $69(65.7)$ & \multirow{2}{*}{0.942} \\
\hline Yes & 15 & $10(66.7)$ & \\
\hline \multicolumn{4}{|l|}{ HT, n (\%) } \\
\hline No & 88 & $58(65.9)$ & \multirow{2}{*}{0.977} \\
\hline Yes & 32 & $21(65.6)$ & \\
\hline \multicolumn{4}{|l|}{ CAD, n (\%) } \\
\hline No & 115 & 77 (67.0) & \multirow{2}{*}{0.337} \\
\hline Yes & 5 & $2(40.0)$ & \\
\hline \multicolumn{4}{|l|}{ Other, n (\%) } \\
\hline No & 116 & $75(64.7)$ & \multirow{2}{*}{0.298} \\
\hline Yes & 4 & $4(100)$ & \\
\hline \multicolumn{4}{|l|}{ Smoking, n (\%) } \\
\hline No & 85 & $57(67.1)$ & \multirow{2}{*}{0.659} \\
\hline Yes & 35 & $22(62.9)$ & \\
\hline \multicolumn{4}{|c|}{ Stone history, n (\%) } \\
\hline No & 74 & $49(66.2)$ & \multirow{2}{*}{0.911} \\
\hline Yes & 46 & $30(65.2)$ & \\
\hline \multicolumn{4}{|c|}{ Family History, n (\%) } \\
\hline No & 104 & $69(66.3)$ & \multirow{2}{*}{0.763} \\
\hline Yes & 16 & $10(62.5)$ & \\
\hline \multicolumn{4}{|l|}{ Creatinine, $\mathrm{n}(\%)$} \\
\hline$<1.2$ & 91 & $59(64.8)$ & \multirow{2}{*}{0.683} \\
\hline$\geq 1.2$ & 29 & $20(69.0)$ & \\
\hline \multicolumn{4}{|l|}{ Side, $\mathrm{n}(\%)$} \\
\hline Left & 65 & $42(64.6)$ & \multirow{2}{*}{0.760} \\
\hline Right & 55 & $37(67.3)$ & \\
\hline \multicolumn{4}{|l|}{ Location, n (\%) } \\
\hline Upper & 6 & $3(50.0)$ & \multirow{5}{*}{0.228} \\
\hline Middle & 29 & $23(79.3)$ & \\
\hline Lower & 20 & $15(75.0)$ & \\
\hline Pelvis & 17 & $9(52.9)$ & \\
\hline Proximal & 48 & $29(60.4)$ & \\
\hline
\end{tabular}

Table 4. Comparison of age, creatinine, stone size and number of ESWL sequence of the patients with and without successful treatment

\begin{tabular}{lccc}
\hline & SFR $(-)(\mathbf{n}=\mathbf{4 1})$ & SFR $(+)(\mathbf{n = 7 9})$ & $\mathbf{p}$ \\
\hline Age (years) & $66.49 \pm 1.52$ & $66.91 \pm 2.27$ & 0.284 \\
Creatinine $(\mathrm{mg} / \mathrm{dL})$ & $0.91 \pm 0.28$ & $0.92 \pm 0.33$ & 0.874 \\
Stone size $(\mathrm{mm})$ & $11.15 \pm 3.13$ & $9.66 \pm 3.42$ & $\mathbf{0 . 0 2 2}$ \\
Number of ESWL & $3(3)[1-8]$ & $2(1)[1-8]$ & $\mathbf{0 . 0 0 8}$ \\
\hline SFR: stone free rate, ESWL: extracorporeal shock wave lithotripsy &
\end{tabular}




\section{DISCUSSION}

Since ESWL is a less invasive procedure and usually does not require anesthesia, it has been considered a suitable treatment alternative for elderly patients (1). In many studies, the incidence of urolithiasis in elderly patients has been reported to be between 7.1 and $23.1 \%(13,14)$. Elderly patients constituted $7 \%$ of all patients who underwent ESWL in our study. In the study of Polat et al. (13) this rate was found to be $13.6 \%$. Ureteral stone location in this study had the worst SFR, but kidney stones had satisfactory SFR. When the SFR success was evaluated according to the stone localization, the highest success was obtained in the middle calyx stone group $(79.3 \%)$, and the lowest success was obtained in the upper calyx stones $(50 \%)$ in the present study. In some studies, SFR after ESWL treatment was higher in younger patients than older patients. An early report evaluating prognostic factors for treatment outcome of kidney stones found that patients over 60 years of age had the lowest SFR of all age groups (15). It was thought that the reason for this might be physiological changes due to senility with a decrease in renal parenchyma thickness and in GFR (14). In some studies, SFR rates after ESWL applied in elderly patients have been reported between $52.1 \%$ and $63.5 \%(16,17)$. In our study, this rate was $65.8 \%$ and correlated with these results $(10,11)$.

When the factors related to SFR such as age, creatinine value, stone size and the number of sessions were compared, the effect of stone size and the number of sessions on SFR was statistically significant. In the study of Abdel-Khalek et al. (18) stone site, stone size and the existence of a ureteral stent had a significant effect on the success rate. In their study, $28(3 \%)$ patients required auxiliary procedures to relieve obstruction and remove residual fragments. Auxiliary procedures were needed in $36(30 \%)$ of the patients after ESWL in our study. This difference is due to the wide age scale (range 5 to 75 years) of the patients in the study of Abdel-Khalek et al. (18).

No procedure was interrupted due to any serious major complications. Mild subcapsular hematoma and pyelonephritis were detected in two patients. They were hospitalized and followed up with appropriate treatment and discharged without any problems. In a study by Polat et al. (13), subcapsular hematoma was found in $3(1.2 \%)$ patients and pyelonephritis was found in one $(0.4 \%)$ patient. Comorbidity was high in this age group expectedly. HT (26.7\%), DM $(12.5 \%)$ and $\mathrm{CAD}(4.2 \%)$ were the most common diseases. In the study of Lamacchia et al. (1), comorbidity rates including HT (66.7\%), CAD (24\%) and DM (18\%) were found to be higher. The difference is due to the fact that the patients in this study were over 70 years of age. The relatively small number of patients and the retrospective design are the main limitations of this study. However, it should be considered that elderly patients receiving ESWL treatment constitutes a small part of the population.

\section{CONCLUSION}

In conclusion, stone size and the number of sessions was statistically significant on SFR in elderly patients. ESWL treatment should be considered an appropriate even the first option for elder male with favorable stone size in kidney and proximal ureteral stones. Furthermore, ESWL caused acceptable morbidity and high efficacy in older patients.
Ethics Committee Approval: The study was approved by the Ethics Committee of Duzce University Faculty of Medicine (06.10.2015, 51).

Conflict of Interest: None declared by the authors.

Financial Disclosure: None declared by the authors.

Acknowledgements: None declared by the authors.

Author Contributions: Idea/Concept: AY; Design: AY, DB; Data Collection/Processing: YŞ, ATT; Analysis/Interpretation: AY, ATT; Literature Review: DB, YŞ; Drafting/Writing: AY; Critical Review: AY, DB.

\section{REFERENCES}

1. Lamacchia GB, Korkes F, Baccaglini W, de Mello LGM, Szwarc M, Tobias-Machado M. A large series of extracorporeal shock-wave lithotripsy in the very elderly. Ther Adv Urol. 2019;11:1756287219870412.

2. Pearle MS, Calhoun EA, Curhan GC; Urologic Diseases of America Project. Urologic diseases in America project: urolithiasis. J Urol. 2005;173(3):84857.

3. Yasui T, Iguchi M, Suzuki S, Kohri K. Prevalence and epidemiological characteristics of urolithiasis in Japan: national trends between 1965 and 2005. Urology. 2008;71(2):209-13.

4. Feng L, Yap KB, Yeoh LY, Ng TP. Kidney function and cognitive and functional decline in elderly adults: findings from the Singapore longitudinal aging study. J Am Geriatr Soc. 2012;60(7):1208-14.

5. Bartoletti R, Cai T, Mondaini N, Melone F, Travaglini F, Carini M, et al. Epidemiology and risk factors in urolithiasis. Urol Int. 2007;79(Suppl 1):3-7.

6. Knoll T, Schubert AB, Fahlenkamp D, Leusmann DB, Wendt-Nordahl G, Schubert G. Urolithiasis through the ages: data on more than 200,000 urinary stone analyses. J Urol. 2011;185(4):1304-11.

7. Yoshida O, Terai A, Ohkawa T, Okada Y. National trend of the incidence of urolithiasis in Japan from 1965 to 1995 . Kidney Int. 1999;56(5):1899-904.

8. Kates M, Matlaga BR. Stones in the elderly. Curr Geri Rep. 2014;3:14-8.

9. Hollingsworth JM, Rogers MA, Kaufman SR, Bradford TJ, Saint S, Wei JT, et al. Medical therapy to facilitate urinary stone passage: a meta-analysis. Lancet. 2006;368(9542):1171-9.

10. Tzelves L, Türk C, Skolarikos A. European Association of Urology Urolithiasis Guidelines: Where are we going? Eur Urol Focus. 2021;7(1):34-8.

11. Zheng C, Yang H, Luo J, Xiong B, Wang H, Jiang Q. Extracorporeal shock wave lithotripsy versus retrograde intrarenal surgery for treatment for renal stones 1-2 cm: a meta-analysis. Urolithiasis. 2015;43(6):549-56.

12. Assimos D, Krambeck A, Miller NL, Monga M, Murad $\mathrm{MH}$, Nelson CP, et al. Surgical Management of Stones: American Urological Association/Endourological Society Guideline, PART I. J Urol. 2016;196(4):115360. 
13. Polat F, Yeșil S, Ak E, Farahvash A, Karaoğlan U, Biri $\mathrm{H}$, et al. Safety of ESWL in elderly: evaluation of independent predictors and comorbidity on stone-free rate and complications. Geriatr Gerontol Int. 2012;12(3):413-7.

14. Ng CF, Wong A, Tolley D. Is extracorporeal shock wave lithotripsy the preferred treatment option for elderly patients with urinary stones? A multivariate analysis of the effect of patient age on treatment outcome. BJU Int. 2007;100(2):392-5.

15. Ackermann DK, Fuhrimann R, Pfluger D, Studer UE, Zingg EJ. Prognosis after extracorporeal shock wave lithotripsy of radioopaque renal calculi: a multivariate analysis. Eur Urol. 1994;25(2):105-9.
16. Philippou P, Lamrani D, Moraitis K, Bach C, Masood J, Buchholz N. Is shock wave lithotripsy efficient for the elderly stone formers? Results of a matched-pair analysis. Urol Res. 2012;40(4):299-304.

17. Sighinolfi MC, Micali S, Grande M, Mofferdin A, De Stefani S, Bianchi G. Extracorporeal shock wave lithotripsy in an elderly population: how to prevent complications and make the treatment safe and effective. J Endourol. 2008;22(10):2223-6.

18. Abdel-Khalek M, Sheir K, Elsobky E, Showkey S, Kenawy M. Prognostic factors for extracorporeal shock-wave lithotripsy of ureteric stones--a multivariate analysis study. Scand J Urol Nephrol. 2003;37(5):413-8. 